\title{
Evaluation on the Developmental Situation of Foreign Tourism in Heilongjiang Province, China
}

\author{
Wang Wei ${ }^{1, a}$, LIU Chang ${ }^{1, b}$, Song Jia ${ }^{1, b}$ and YAO Yongzhi ${ }^{2, c}{ }^{*}$ \\ ${ }^{1}$ School of Graduate, Harbin University of Commerce, Harbin, P.R.China \\ ${ }^{2}$ School of Humanities and Social Science, Harbin Institute of Technology, Harbin, P.R.China \\ Awwww_1215@163.com, b1010370682@qq.com, cyyz002@hit.edu.cn
}

Keywords: Foreign tourism; Developmental situation; Evaluation; Suggestion

\begin{abstract}
In the study an evaluation system was set up, which can be used to evaluated on foreign tourism development in Heilongjiang province, China, then the following problems were reflected on, such as unbalanced developing competence of foreign trade, weakening developing potential influenced by trade deficit, low ability to attract foreign investment, depressing situation in the tourism industry and so on. Some rational suggestions were proposed, such as promoting the economic hinterland for foreign trade vigorously, increasing the construction of foreign trade port, creating a nice environment to attract foreign investment, establishing a mechanism for inner competition of tourism industry, strengthening the comprehensive transportation capacity and so on.
\end{abstract}

\section{Introduction}

Heilongjiang province is located in the northeast of China with a border of 2981 kilometers and 25 open ports on national level. It is the second largest port province after Guangdong and the biggest one which trades with Russia on forestry, mineral, oil and gas, power and agricultural cooperation. It is located in the northeast of Asia, so it is also a major channel, a large base for development, a large platform, a reservoir and leisure place, which plays a leading role in the fields of economic, trade, logistics, tourism and so on. Heilongjiang lies in the area with temperate continental monsoon climate of medium latitudes with four distinct seasons and abundant resources such as forest, river, lakes, wetland, lava, great oil field, big farms and other ecological resources. It is also famous for the culture of ice and snow both in China and abroad. Besides, it also has a exotic and unique folk culture, so that it has a very deep potential to develop tourism. [1]

In the developing strategy of Eight Economic Zones in Heilongjiang Province, Northeast Asia Economic and Trade Development Zone, Ha Mu Suidong Trade Processing Zones relevant to Russia and Scenery Tourism Development Zones in the north contribute to the further development of foreign trade and international economic and trade cooperation as well as the further scientific and standardized development in the tourism industry. Besides, it also provided the new historical opportunity for the development of foreign tourism in Heilongjiang Province. At present, substantive progress has been made in the open-up in Heilongjiang Province, such as Suifenhe national comprehensive bonded area, the protection, open-up and developing in Heixiazi Island and the Northeast Asia Trade Developing Zone. [2],[3] All these achievements have injected new vitality into foreign tourism development, which is playing a leading role in revitalizing the economy, promoting a healthy development in the economy all across Heilongjiang Province, saving resources and protecting the environment, as well as improving the income level of labor.

The government of Heilongjiang Province presented the developing strategy for establishing Five Plans and Ten Major Industries in 2014. Foreign tourism development across Heilongjiang province has achieved remarkable results, but there are still some problems. The study intends to explore the corresponding countermeasures and provides a reference for the governments and relative departments to make decisions. 


\section{Evaluation System of Foreign Tourism Development}

The key to objectively evaluate developing situation and potential of foreign tourism in Heilongjiang province is establishing a comprehensive and scientific evaluation system. According to the national economic and social development statistical bulletin in Heilongjiang Province during 2007-2011, and the relevant data of its statistical yearbook during 2008-2012, the establishment of the index system for foreign tourism is shown in Table 1.[4],[5]

Table 1 Evaluation system of foreign tourism

\begin{tabular}{|c|c|c|}
\hline $\begin{array}{l}\text { First grade } \\
\text { indicators }\end{array}$ & $\begin{array}{l}\text { Second grade } \\
\text { indicators }\end{array}$ & Third grade indicators \\
\hline \multirow{14}{*}{$\begin{array}{l}\text { Foreign Trade } \\
\text { and Tourism }\end{array}$} & \multirow{4}{*}{$\begin{array}{l}\text { import and export } \\
\text { trade indicator, } A\end{array}$} & $\begin{array}{l}\text { total volume of foreign trade (ten thousand dollars), } \\
a_{1}\end{array}$ \\
\hline & & $\begin{array}{l}\text { total volume of foreign trade /GDP (exchange rate, } \\
\text { similarly hereinafter) }, a_{2}\end{array}$ \\
\hline & & total volume of export ( ten thousand dollars),$a_{3}$ \\
\hline & & total volume of import. (ten thousand dollars ), $a_{4}$ \\
\hline & \multirow{3}{*}{$\begin{array}{l}\text { foreign direct } \\
\text { investment indicator, } \\
B\end{array}$} & direct investment projects (numbers),$b_{1}$ \\
\hline & & contract amount (ten thousand dollars),$b_{2}$ \\
\hline & & actual use of investment (ten thousand dollars),$b_{3}$ \\
\hline & \multirow{3}{*}{$\begin{array}{l}\text { open-up indicator in } \\
\text { tourism industry, } C\end{array}$} & $\begin{array}{l}\text { international tourism foreign exchange earning (a } \\
\text { hundred million dollars }), c_{1}\end{array}$ \\
\hline & & tourism exchange earning/GDP, $c_{2}$ \\
\hline & & inbound passengers (ten thousand),$c_{3}$ \\
\hline & \multirow{4}{*}{$\begin{array}{l}\text { developing indicator } \\
\text { in tourism industry, } D\end{array}$} & $\begin{array}{l}\text { total revenue in tourism industry (one hundred million } \\
\text { yuan) } d_{l}\end{array}$ \\
\hline & & total revenue in tourism industry/GDP $(\%): d_{2}$ \\
\hline & & domestic travelers (ten thousand ) $d_{3}$ \\
\hline & & $\begin{array}{l}\text { total revenue in domestic tourism( one hundred million } \\
\text { yuan ) } d 4\end{array}$ \\
\hline
\end{tabular}

In Table 1, there are 4 two-grade indicators and 14 three-grade indicators. The two-grade indicators include foreign trade, foreign direct investment, open-up in tourism industry and tourism development, which mainly reflect the development situation of foreign trade, foreign investment all around Heilongjiang, the development potential of international tourism development and tourism inside the province. Three-grade indicators are used to further analyze the actual situation of the development of foreign trade and the tourism industry around the province.

Calculation steps of comprehensive evaluation index mainly includes three parts. Firstly, calculate the three grades index score one by one according to the provincial statistics bulletin and the published data in Statistical Yearbook. Second, make the average of a standard value of 13 cities in Heilongjiang 5 points, then calculate respectively according to the nature of the three grades indicators (or inverse indicators, and positive indicators is favorite here), and Table 2 shows the calculation method. Third, calculate the score of three grades respectively.[6],[7],[8] 
Table 2 Calculation method of evaluation system of foreign tourism

\begin{tabular}{|c|c|c|c|c|c|c|}
\hline \multirow{2}{*}{$\begin{array}{l}\text { First Grade } \\
\text { Indicators }\end{array}$} & \multirow{2}{*}{$\begin{array}{l}\text { Second } \\
\text { Grade } \\
\text { Indicators }\end{array}$} & \multirow{2}{*}{$\begin{array}{l}\text { Third } \\
\text { Grade } \\
\text { Indicators }\end{array}$} & \multirow{2}{*}{$\begin{array}{l}\text { Standard } \\
\text { Values }\end{array}$} & \multirow{2}{*}{$\begin{array}{l}\text { Standard } \\
\text { Score }\end{array}$} & \multicolumn{2}{|c|}{ Actual Index Score } \\
\hline & & & & & $\begin{array}{l}\text { Positive } \\
\text { Indicators }\end{array}$ & $\begin{array}{l}\text { Inverse } \\
\text { Indicators }\end{array}$ \\
\hline \multirow{4}{*}{$T=\Sigma \mathrm{Mi}$} & $\begin{array}{c}A=\mathrm{M} 1 \\
=\Sigma \mathrm{ai}\end{array}$ & ai & $\bar{a}_{\mathrm{i}}$ & 5 & $a=5 \times \frac{a_{i}}{\bar{a}_{i}}$ & $a=5 \times \frac{\bar{a}_{i}}{a_{i}}$ \\
\hline & $\begin{array}{c}B=\mathrm{M} 2 \\
=\Sigma \mathrm{bi}\end{array}$ & bi & $\overline{\mathrm{b}}_{\mathrm{i}}$ & 5 & $b=5 \times \frac{b_{i}}{\bar{b}_{i}}$ & $b=5 \times \frac{\bar{b}_{i}}{b_{i}}$ \\
\hline & $\begin{aligned} C & =\mathrm{M} 3 \\
& =\Sigma \mathrm{ci}\end{aligned}$ & $\mathrm{ci}$ & $\overline{\mathrm{c}}_{\mathrm{i}}$ & 5 & $c=5 \times \frac{c_{i}}{\bar{c}_{i}}$ & $c=5 \times \frac{\bar{c}_{i}}{c_{i}}$ \\
\hline & $\begin{array}{c}D=\mathrm{M} 4 \\
=\Sigma \mathrm{di}\end{array}$ & di & $\overline{\mathrm{d}}_{\mathrm{i}}$ & 5 & $d=5 \times \frac{d_{i}}{\bar{d}_{i}}$ & $d=5 \times \frac{\bar{d}_{i}}{d_{i}}$ \\
\hline
\end{tabular}

\section{Calculation of Standard Scores in 13 Cities of Heilongjiang}

According to sorting data in the statistical bulletin of national economic and social development of Heilongjiang province during 2007-2011, we can get the average value of third-grade indicators of the 13 cities in Heilongjiang province, we can calculate the scores of some cities have lost relevant data according to the average value of the cities that have relevant data. If we calculate the average value of the total value of foreign trade in 2011, we will need the average of the sum of total value of foreign trade in the 13 cities in 2011, of which $\$ 4908770000$ in Harbin, \$1028880000 in Qigihar, \$923490000 in Jixi, \$111720000 in Hegang, \$1306900000 in Shuangyashan, \$2158960000 in Daqing, \$347850000 in Yichun, Jiamusi \$3651510000, \$92680000 in Qitaihe, \$10422560000 in Mudanjiang, $\$ 3283380000$ in Heihe, $\$ 131510000$ in Suihua, $\$ 887140000$ in Daxinganling, and the average is $\$ 225041.2$. The average value of third-grade indicators in the 13 cities in Heilongjiang province during 2007 to 2011 is shown in Table 3.

Table 3 Mean value of third-grade indicators of the 13 cities in Heilongjiang from 2007 to 2011

\begin{tabular}{|c|c|c|c|c|c|c|}
\hline $\begin{array}{l}\text { Second Grade } \\
\text { Indicators }\end{array}$ & Third Grade Indicators & 2007 & 2008 & 2009 & 2010 & 2011 \\
\hline \multirow{4}{*}{$\begin{array}{l}\text { foreign trade } \\
\text { indicator } \mathrm{A}\end{array}$} & $\begin{array}{l}\text { total value of foreign } \\
\text { trade (ten thousand } \\
\text { dollars) }\end{array}$ & 130692.8 & 136025.0 & 120641.1 & 183519.1 & 225041.2 \\
\hline & $\begin{array}{c}\text { total value of foreign } \\
\text { trade /GDP }\end{array}$ & $27.2 \%$ & $25.1 \%$ & $15.6 \%$ & $19.8 \%$ & $21.8 \%$ \\
\hline & $\begin{array}{l}\text { total value of export (ten } \\
\text { thousand dollars) }\end{array}$ & 92716.1 & 102519.8 & 75549.7 & 117127.4 & 114884.4 \\
\hline & $\begin{array}{l}\text { total value of import (ten } \\
\text { thousand dollars) }\end{array}$ & 37976.7 & 33505.2 & 45091.5 & 66391.8 & 110156.8 \\
\hline \multirow{3}{*}{$\begin{array}{l}\text { foreign direct } \\
\text { investment } \\
\text { indicators B }\end{array}$} & $\begin{array}{c}\text { direct investment } \\
\text { projects (numbers) }\end{array}$ & 18.5 & 12.2 & 12.2 & 11.2 & 10.9 \\
\hline & $\begin{array}{l}\text { contract investment } \\
\text { (ten thousand dollars) }\end{array}$ & 12722.2 & 12936.8 & 8865.0 & 22085.1 & 27141.5 \\
\hline & $\begin{array}{l}\text { actual use of investment } \\
\text { (ten thousand dollars) }\end{array}$ & 6305.2 & 8792.8 & 8632.5 & 20473.2 & 24984.9 \\
\hline \multirow{2}{*}{$\begin{array}{l}\text { open-up } \\
\text { indicators in } \\
\text { tourism } \\
\text { industry C }\end{array}$} & $\begin{array}{l}\text { international tourism } \\
\text { earning (one hundred } \\
\text { million dollars) }\end{array}$ & 0.61 & 0.78 & 0.88 & 0.99 & 1.15 \\
\hline & tourism earning/GDP & $0.92 \%$ & $0.92 \%$ & $0.73 \%$ & $0.74 \%$ & $0.65 \%$ \\
\hline
\end{tabular}




\begin{tabular}{|c|c|c|c|c|c|c|}
\hline & $\begin{array}{l}\text { inbound tourists（ten } \\
\text { thousand person） }\end{array}$ & 17.38 & 17.23 & 10.95 & 13.21 & 28.69 \\
\hline \multirow{4}{*}{$\begin{array}{l}\text { developing } \\
\text { indicator in } \\
\text { tourism } \\
\text { industry D }\end{array}$} & $\begin{array}{l}\text { total value in tourism } \\
\text { industry (one hundred } \\
\text { million yuan) }\end{array}$ & 29.6 & 36.9 & 46.0 & 61.9 & 84.9 \\
\hline & $\begin{array}{l}\text { total value in tourism } \\
\text { industry /GDP }\end{array}$ & $4.0 \%$ & $5.1 \%$ & $6.0 \%$ & $7.1 \%$ & $8.6 \%$ \\
\hline & $\begin{array}{l}\text { domestic tourists (ten } \\
\text { thousand person) }\end{array}$ & 531.2 & 580.4 & 691.3 & 851.3 & 1397.2 \\
\hline & $\begin{array}{l}\text { domestic tourism } \\
\text { earning (one hundred } \\
\text { million yuan) }\end{array}$ & 34.0 & 40.8 & 78.7 & 97.8 & 120.6 \\
\hline
\end{tabular}

Table 4 shows that the development of foreign trade and tourism industry in the 13 cities in Heilongjiang province is seriously polarized and only Harbin and Mudanjiang have experienced a high degree of developing. In the second-grade indicators, we can have the following conclusions, firstly, the developing degree in Harbin, Mudanjiang, Jiamusi and Heihe is higher. Secondly, the ability to attract foreign direct investment is strong in Harbin and Mudanjiang while it is unstable in Qiqihaer and Daqing. Thirdly, the degree of open-up in Mudanjiang ranks first across Heilongjiang province, while the level of open-up in Harbin declined year after year and even not reached the standard line in 2011. Finally, in developing level of the tourism industry, it is much higher in Harbin and Qiqihaer than the other regions.

Table 4 Cities up to the standard in foreign tourism development in Heilongjiang from 2007 to 2011

\begin{tabular}{|c|c|c|c|c|c|c|c|c|c|c|c|}
\hline \multirow{2}{*}{\multicolumn{2}{|c|}{ indicator }} & \multicolumn{2}{|c|}{2007} & \multicolumn{2}{|c|}{2008} & \multicolumn{2}{|c|}{2009} & \multicolumn{2}{|c|}{2010} & \multicolumn{2}{|c|}{2011} \\
\hline & & Cities & score & Cities & score & Cities & score & Cities & score & Cities & score \\
\hline \multicolumn{2}{|c|}{$\begin{array}{l}\text { First-grade } \\
\text { indicator }\end{array}$} & $\begin{array}{l}\text { Harbin } \\
\text { Mudanj } \\
\text { iang }\end{array}$ & $\begin{array}{l}252.05 \\
226.98\end{array}$ & $\begin{array}{l}\text { Harbin } \\
\text { Mudanj } \\
\text { iang }\end{array}$ & $\begin{array}{l}268.08 \\
258.27\end{array}$ & $\begin{array}{l}\text { Harbin } \\
\text { Mudanj } \\
\text { iang }\end{array}$ & \begin{tabular}{|l}
270.85 \\
191.29
\end{tabular} & $\begin{array}{l}\text { Harbin } \\
\text { Mudanji } \\
\text { ang }\end{array}$ & $\begin{array}{l}239.00 \\
194.07\end{array}$ & $\begin{array}{l}\text { Harbin } \\
\text { Mudanji } \\
\text { ang }\end{array}$ & $\begin{array}{l}214.06 \\
138.71\end{array}$ \\
\hline \multirow{4}{*}{$\begin{array}{c}\text { Second } \\
\text { grade } \\
\text { indicator }\end{array}$} & $\begin{array}{l}\text { Foreign } \\
\text { trade }\end{array}$ & $\begin{array}{l}\text { Mudanj } \\
\text { iang } \\
\text { Heihe } \\
\text { Harbin } \\
\text { Jiamusi }\end{array}$ & $\begin{array}{l}118.09 \\
43.35 \\
39.53 \\
24.23 \\
\end{array}$ & $\begin{array}{l}\text { Mudanj } \\
\text { iang } \\
\text { Harbin } \\
\text { Heihe } \\
\text { Jiamusi }\end{array}$ & $\begin{array}{l}147.61 \\
49.54 \\
46.17 \\
28.85\end{array}$ & $\begin{array}{l}\text { Mudanj } \\
\text { iang } \\
\text { Harbin } \\
\text { Heihe } \\
\text { Jiamusi }\end{array}$ & $\begin{array}{l}86.85 \\
45.16 \\
39.37 \\
32.91\end{array}$ & $\begin{array}{l}\text { Mudanji } \\
\text { ang } \\
\text { Harbin } \\
\text { Heihe } \\
\text { Jiamusi }\end{array}$ & $\begin{array}{l}99.31 \\
38.78 \\
39.43 \\
32.23\end{array}$ & $\begin{array}{l}\text { Mudanji } \\
\text { ang } \\
\text { Harbin } \\
\text { Heihe } \\
\text { Jiamusi }\end{array}$ & $\begin{array}{l}62.75 \\
34.50 \\
34.12 \\
30.44\end{array}$ \\
\hline & $\begin{array}{c}\text { Foreign } \\
\text { direct } \\
\text { indicator }\end{array}$ & $\begin{array}{l}\text { Harbin } \\
\text { Daqing } \\
\text { Mudanj } \\
\text { iang } \\
\text { Qiqihar }\end{array}$ & $\begin{array}{l}93.28 \\
24.84 \\
20.24 \\
15.79\end{array}$ & $\begin{array}{l}\text { Harbin } \\
\text { Daqing } \\
\text { Mudanj } \\
\text { iang }\end{array}$ & $\begin{array}{l}100.03 \\
18.98 \\
16.80\end{array}$ & $\begin{array}{l}\text { Harbin } \\
\text { Mudanj } \\
\text { iang }\end{array}$ & $\begin{array}{l}116.10 \\
23.06\end{array}$ & $\begin{array}{l}\text { Harbin } \\
\text { Daqing } \\
\text { Mudanji } \\
\text { ang } \\
\text { Qiqihar }\end{array}$ & $\begin{array}{l}99.83 \\
21.48 \\
18.18 \\
18.07\end{array}$ & $\begin{array}{l}\text { Harbin } \\
\text { Daqing } \\
\text { Mudanji } \\
\text { ang }\end{array}$ & $\begin{array}{l}97.25 \\
21.55 \\
15.57\end{array}$ \\
\hline & $\begin{array}{l}\text { Open-up } \\
\text { in } \\
\text { tourism } \\
\text { industry }\end{array}$ & $\begin{array}{l}\text { Mudanj } \\
\text { iang } \\
\text { Harbin }\end{array}$ & $\begin{array}{l}67.09 \\
22.59\end{array}$ & $\begin{array}{l}\text { Mudanj } \\
\text { iang } \\
\text { Harbin }\end{array}$ & $\begin{array}{l}74.18 \\
22.53\end{array}$ & $\begin{array}{l}\text { Mudanj } \\
\text { iang } \\
\text { Harbin }\end{array}$ & $\begin{array}{l}63.55 \\
21.64\end{array}$ & $\begin{array}{l}\text { Mudanji } \\
\text { ang } \\
\text { Harbin }\end{array}$ & $\begin{array}{l}61.10 \\
19.01\end{array}$ & $\begin{array}{l}\text { Mudanji } \\
\text { ang }\end{array}$ & 48.19 \\
\hline & $\begin{array}{l}\text { Develop } \\
\text { ment of } \\
\text { tourism } \\
\text { industry }\end{array}$ & $\begin{array}{l}\text { Harbin } \\
\text { Qiqihar } \\
\text { Mudanj } \\
\text { iang }\end{array}$ & $\begin{array}{l}96.65 \\
28.24 \\
21.56\end{array}$ & $\begin{array}{l}\text { Harbin } \\
\text { Qiqihar }\end{array}$ & $\begin{array}{l}95.98 \\
26.46\end{array}$ & $\begin{array}{l}\text { Harbin } \\
\text { Qiqihar }\end{array}$ & $\begin{array}{l}87.95 \\
26.59\end{array}$ & $\begin{array}{l}\text { Harbin } \\
\text { Qiqihar }\end{array}$ & $\begin{array}{l}81.38 \\
24.26\end{array}$ & $\begin{array}{l}\text { Harbin } \\
\text { Qiqihar }\end{array}$ & $\begin{array}{l}68.09 \\
21.10\end{array}$ \\
\hline
\end{tabular}

\section{Countermeasures to promote foreign tourism development in Heilongjiang}

The first is developing economic hinterland of foreign trade energetically. We should target the development of the spatial pattern based on the city group, make sure the optimal allocation of 
production factors and market docking, establish industrial chains which are complementary and synergistic and further innovating system and mechanism so that we can create a favorable policy environment for developing the economic hinterland. [9]

The second, it is intensifying the construction of foreign trade ports, improving the function and capacity of the ports in order to integrate customs, which includes strengthening the port infrastructure construction, coordinating the supporting service institutes such as inspection and other supporting work, actively promoting the construction of electronic information platform, and strengthening communication with the Russian customs etc.

The third is creating a favorable environment to attract foreign investment. We should strengthen the service function of our government, improve the ability to prevent risks, strengthen the introduction of infrastructure and new technology, and further increase attractiveness for foreign capital. Therefore, we should create a beautiful and liberal investment environment to attract foreign-funded enterprises and projects which can provide us capital and technology.[10],[11]

The forth, it is establishing the mechanism for internal competition, improving the competition and service awareness in tourism industry, which includes the transformation of the developing concept and the operating mode, enriching the existing characteristic tourism resources in Heilongjiang (such as ice and snow tourism) in order to further exploring the developing potential of the tourism industry.

Finally, it is strengthening the construction of comprehensive traffic transportation capacity, which includes scientific management of the existing transportation lines, appropriate control of the scale of traffic infrastructure construction, enhancing technological content in infrastructure renewal, further developing modern logistics industry and other ancillary services and improving the quality of transportation services.

\section{Acknowledgment}

This work is partially supported by the Humanities and Social Sciences Fund of Ministry of Education under Grant 12YJC790190, the young academic backbone support program under Grant 1253G029 in Heilongjiang Province, SSFC under Grant 13AZD071, National Soft Science Research Project under Grant 2013GXS2D020 in China, and Postdoctoral Scientific Research Initiation Grant LBH-Q14094, the Soft Science Technology Foundation under Grant GC13D101, QC07C117 in Heilongjiang Province, China.

\section{References}

[1] Bingxuan Ji, Exploring the geo-advantage of Heilongjiang in the process of deepening open-up, Journal of Qiu Shi, 1 (2013) 15-17.

[2] Li Xiaojia, Liu Peng, China's economic growth and energy consumption empirical study based on the cointegration and state space model estimation, Soft Science, 8 (2009) 61-64.

[3] Xia Xiangyang, Rural labor employment security research under the Maslow's hierarchy of needs theory, Anhui Agricultural Sciences, 23 (2011) 14473-14474.

[4] Fuming Sun, Song Qing, A study on the comparative resources of the economical society in the six provinces of east China, Journal of Harbin University of Commerce (Social Sciences). 5 (2012) 71-77.

[5] Fuming Sun, Song Qing, A study on evaluation index system for resource-saving society, Journal of Jimei University (Philosophy and Social Sciences), 4 (2012) 55-60.

[6] Wang Wei, Zhao Dawei, Investigation on the employment situation of family attendants in China. China Population Resourses and Environment, 22(5), (2012) 192-194. 
[7] Wang Wei, Liu Yuxin, Wang Zhihao, On influencing factors of rural labor force employment based on the state space model in Heilongjiang province, Mathematics in Practice and Theory, 44(12), (2014) 63-71.

[8] Wang Wei, Liu Yuxin, Wang Zhihao, linkage effects of employment, wage, pension Insurance of urban employees in China, China Management Science, 22S1 (2014) 617-622.

[9] Liu Zheng, Analysis of the influence factors of rural labor employment, Journal of Anhui Agricultural Sciences, 21 (2012) 11111-11113.

[10] Xu Bo,Zhao Chunyu,Fan Shuping,Zhao Lingli, Study on the employment spatial behavior of rural labor force in China, Journal of Subtropical Resources and Environment, 2 (2010) 19-24.

[11] Xue Huihui,Wei Feng, Selectiong of rural labor force activity circle and analysis of its influencing factors in Shaanxi Province, Southern Agricultural Sciences, 1 (2013) 176-180. 